\title{
Testing a Passive Revegetation Approach for Restoring Coastal Plain Depression Wetlands
}

\author{
Diane De Steven, ${ }^{1,2}$ Rebecca R. Sharitz, ${ }^{3}$ Julian H. Singer, ${ }^{3}$ and Christopher D. Barton ${ }^{4}$
}

\begin{abstract}
Restoration of coastal plain depressions, a biologically significant and threatened wetland type of the southeastern United States, has received little systematic research. Within the context of an experimental project designed to evaluate several restoration approaches, we tested whether successful revegetation can be achieved by passive methods (recruitment from seed banks or seed dispersal) that allow for wetland "self-design" in response to hydrologic recovery. For 16 forested depressions that historically had been drained and altered, drainage ditches were plugged to reestablish natural ponding regimes, and the successional forest was harvested to open the sites and promote establishment of emergent wetland vegetation. We sampled seed bank and vegetation composition 1 year before restoration and monitored vegetation response for 3 years after. Following forest removal and ditch plugging, the restored wetlands quickly developed a dense cover of herbaceous plant species, of which roughly half were
\end{abstract}

wetland species. Seed banks were a major source of wetland species for early revegetation. However, hydrologic recovery was slowed by a prolonged drought, which allowed nonwetland plant species to establish from seed banks and dispersal or to regrow after site harvest. Some nonwetland species were later suppressed by ponded conditions in the third year, but resprouting woody plants persisted and could alter the future trajectory of revegetation. Some characteristic wetland species were largely absent in the restored sites, indicating that passive methods may not fully replicate the composition of reference systems. Passive revegetation was partially successful, but regional droughts present inherent challenges to restoring depressional wetlands whose hydrologic regimes are strongly controlled by rainfall variability.

Key words: Carolina bays, depression wetlands, drought effects, isolated wetlands, revegetation, seed banks, wetland restoration.

\section{Introduction}

Across the Atlantic Coastal Plain province of the southeastern United States, Carolina bays and similar depression wetlands are common features that can range in size from one to hundreds of hectares. With hydrologic regimes ranging from semipermanent to seasonal, these biologically diverse wetlands are dominated by aquatic or emergent vegetation but can also support hydrophytic shrub bog and swamp forest (Sharitz \& Gresham 1998; De Steven \& Toner 2004). They are regionally significant in harboring many rare plant species and providing critical wildlife habitat, particularly for pond-breeding amphibians (Pechmann et al. 1989; Snodgrass et al. 1996; Taylor et al. 1999; Edwards \& Weakley 2001). Coastal plain depressions have been widely impacted across their geographic range by drainage and conversion to agrarian uses: some estimates (e.g., Bennett \& Nelson 1991) suggest that less than $10 \%$ currently remain intact or undisturbed. The degree of hydrologic alteration ranges from single surface

${ }^{1}$ USDA Forest Service, Southern Research Station, Center for Bottomland

Hardwoods Research, PO Box 227, Stoneville, MS 38776, U.S.A.

${ }^{2}$ Address correspondence to D. De Steven, email ddesteven@fs.fed.us

${ }^{3}$ Savannah River Ecology Laboratory, University of Georgia, Drawer E, Aiken,

SC 29802, U.S.A.

${ }^{4}$ Department of Forestry, University of Kentucky, Lexington, KY 40546, U.S.A.

Journal compilation (C) 2006 Society for Ecological Restoration International No claim to original US government works ditches that drain smaller wetlands for cropping to extensive ditching and bedding of large Carolina bays for plantation forestry (Sharitz \& Gresham 1998). Some small depressions have been entirely lost to urban development or other land conversions. Because recent changes in U.S. federal regulations have eliminated most protections for "isolated" depressional wetlands, they are now even more susceptible to alteration or destruction (Sharitz 2003; Tiner 2003). Thus, given their distinctive biodiversity and habitat functions, their conservation and restoration are significant regional concerns (e.g., Southern Environmental Law Center 2004).

There has been little systematic research on restoring coastal plain depression wetlands. Where ditching is not severe, natural hydrologic regimes might be restored simply by plugging the ditches, similar to the approach commonly used to restore prairie pothole depression wetlands in the midcontinental United States (Galatowitsch \& van der Valk 1996; Seabloom \& van der Valk 2003). If the hydrologic regime recovers, it is thought that wetland vegetation could establish rapidly through recruitment from relict seed banks and natural dispersal (efficient community hypothesis of Galatowitsch \& van der Valk 1996; see also Palmer et al. 1997). If successful, this "passive" revegetation approach would offer a lower-cost restoration option compared to more "active" and expensive measures of seeding or planting. To date, a preliminary study 
in a drained coastal plain depression in South Carolina demonstrated that ditch plugging could enhance ponding and that the seed bank could supply wetland species to the vegetation under certain conditions (Singer 2001).

Use of passive restoration might be successful in the long term because hydrologic conditions are expected to select for wetland plant species and allow for "self-design" of vegetation composition (Mitsch \& Wilson 1996). However, this approach may have several drawbacks in the short term as initial conditions during the first few years can affect vegetation development. Diverse seed banks have been found in undisturbed depression wetlands (Kirkman \& Sharitz 1994; Collins \& Battaglia 2001), but the seed banks of disturbed depressions might have few wetland species, and plant recolonization by seed dispersal could be too slow to compensate. Depending in part upon land uses in the surrounding uplands, there could also be negative "founder effects" whereby weedy or other undesired species colonize first and then prevent or slow establishment of desired wetland species. Finally, the southeastern United States experiences periodic droughts during which wetland depressions dry down completely (Kirkman 1995; Stroh 2004; Mulhouse et al. 2005b), a feature that may complicate efforts to quickly restore favorable hydrology for wetland plants. The typical time periods for evaluating restorations for regulatory purposes (3-5 years) may be too short to successfully meet vegetation goals without using more active seeding or planting methods.

To address these issues, we present early results from a component study in a replicated experimental project to restore small coastal plain depressions on the Savannah River Site (SRS) in South Carolina, United States (Barton et al. 2004). Depressions used in the project were drained by outflowing surface ditches but had developed a successional forest cover after being abandoned from agricultural uses for several decades (Kirkman et al. 1996). The project's core experiment was designed to test whether restoration can be achieved by harvesting out the overstory forest and plugging the drainage ditches to increase water retention and hydroperiod. Because forest harvest scarifies soils and stimulates seed bank germination, this experiment provided an initial test of the passive revegetation model. The expectation was that restored hydrologic regimes would suppress nonwetland species and favor wetland species that recruit from the seed bank or rapidly colonize by seed dispersal. We describe the overall project and then address two specific questions: (1) how early vegetation development responded to forest removal and hydrologic restoration and (2) whether seed banks were adequate sources of wetland plant species for the restored vegetation.

\section{Project Location and Description}

The SRS is a U.S. Department of Energy (DOE) National Environmental Research Park and former nuclear materi- als facility located on the South Carolina Upper Coastal Plain. Historically, this $800-\mathrm{km}^{2}$ area was mainly an agricultural landscape, but most of the land is now in managed pine, pine-hardwood, and bottomland forests. Of approximately 300 Carolina bays and smaller depression wetlands on the SRS, a majority had been altered in the early- to mid-1900s by ditching, draining, and timber removal for purposes of grazing or farming. After the SRS was established in 1951, these disturbed depressions were either reforested with pines or developed by natural succession to various vegetation types, depending upon the extent to which remnant ditches ceased to function and ponding regimes recovered (Kirkman et al. 1996; De Steven \& Toner 2004).

The climate is humid subtropical with a mean annual rainfall of 1,200 $\mathrm{mm}$, but the region experiences multiyear droughts at intervals on the order of decades (South Carolina State Climatology Office 2004). During the present study, the commencement in 1999 of 4 years with belownormal rainfall (approximately $-175 \mathrm{~mm}$ each year) resulted in a cumulative rainfall deficit of $-740 \mathrm{~mm}$ and severe drought by late 2002. Rains returned at the end of 2002, and annual rainfall for 2003 was $475 \mathrm{~mm}$ above normal.

\section{Project Design}

Nineteen small wetland depressions $0.3-1.7$ ha $(0.7-4.0$ acres) in size, all with one or two actively flowing remnant ditches, were selected for the project. The depressions were widely distributed across major landform settings and had sandy or clayey Ultisol soils (Arenic or Typic Ochraquults in the Ogeechee, Williman, or Rembert series). Prerestoration data on multiple system components (hydrology, vegetation, and fauna) were collected in 2000 by various researchers (Barton et al. 2004). All depressions were dominated by planted or successional forest of tree species also found in adjacent uplands, such as Loblolly pine (Pinus taeda L.), Sweetgum (Liquidambar styraciflua L.), oaks (Quercus nigra L., Q. phellos L., Q. laurifolia Michx.), and Red maple (Acer rubrum L.). In general, depressions with this present-day forest composition were the most disturbed historically, and they typically hold water for only short periods in the dormant season (De Steven \& Toner 2004).

Of the 19 depressions, 16 were randomly selected for experimental restoration, and the remaining 3 were left unmanipulated as "controls" for other research studies and for documenting the extent to which vegetation varied annually without restoration. Depression perimeters were delineated based on microtopography and upland vegetation. To restore the 16 experimental wetlands, the depression interiors were completely harvested to remove the forest cover and open the sites to full sun at ground level. At the wetland perimeters, ditch outlets were plugged to perimeter elevation with low-permeability clay (Barton et al. 2004). Forest removal was completed between 
November 2000 and February 2001, except for one wetland, which could not be harvested until winter 2002. Some slash from tree delimbing was left behind, so the initial condition of the wetland interiors was mostly bare soils with scattered woody debris and stumps. Ditch plugging did not occur until the end of 2001 owing to regulatory permit delays, but this had little impact on restoration progress because drought conditions in 2001 resulted in minimal water ponding or outflow and because ditches were partially blocked by mechanical skidder activity during tree harvest. To control stump resprouting of harvested trees during the first growing season, new shoots were sprayed directly with a foliar herbicide approved for wetland use (Garlon 4) in summer 2001.

In all experimental wetlands, the principal revegetation approach relies on recruitment from seed banks and, secondarily, colonization by seed dispersal. Additional project components are testing other active techniques for restoring wetland plant species and for managing the wetlands. For example, as part of a longer-term project goal, experimental wetlands were assigned in a split-plot design to one or the other of two methods for managing surrounding upland forest buffers (thinned or not thinned) (Barton et al. 2004). Initial restoration goals are to lengthen hydroperiods and to develop emergent vegetation dominated by wetland (hydrophytic) plant species. After 5 years, assessments will evaluate whether the restored sites meet regulatory criteria for wetland hydroperiod (Environmental Laboratory 1987) and whether plant composition falls within the range of values for reference wetlands (De Steven \& Toner 2004). Successfully restored depressions will be credited to a mitigation bank as compensation for potential future impacts to other wetlands on the SRS (Barton et al. 2004).

\section{Methods}

\section{Hydrologic Monitoring}

Beginning in 2000, surface water depth was monitored with fixed staff gauges and a shallow monitoring well placed at the deepest point of each wetland. Hydroperiod during the growing season (April to November) was calculated as percentage of days ponded (i.e., water depth $>0$ ) for each year. Annual rainfall totals were averaged from seven SRS monitoring stations and compared to the 30year average ("normal" rainfall) at a nearby National Oceanic and Atmospheric Administration weather station in Blackville, South Carolina.

\section{Seed Bank and Vegetation Sampling}

Prior to restoration, soil seed banks in 14 of the experimental wetlands were sampled along four radial transects from each wetland center, with three sample points per transect stratified by depth contour intervals within each wetland basin. At each point, a composited sample of
20 soil cores of $2.54-\mathrm{cm}$ diameter and $0-$ to $10-\mathrm{cm}$ depth was collected from a $1-\mathrm{m}^{2}$ plot. Samples were collected between October 1999 and January 2000 and stored at $3-4{ }^{\circ} \mathrm{C}$ for $2-4$ months; they were then sieved through a coarse screen and spread out in shallow trays arrayed randomly in a greenhouse maintained under natural sunlight and air-conditioned not to exceed $35^{\circ} \mathrm{C}$ (typical summer daytime high temperature). All emerging seedlings were counted and removed as they were identified. Greenhouse space limitations precluded running parallel trials of different germination conditions. Instead, trays were first maintained under moist conditions (well watered and drained) for approximately 6 months until emergence ceased, after which they were flooded continuously above the soil surface for an additional 3 months until any new emergence ended. In general, there was little emergence from the flooded treatment. Seedling counts in the 12 replicate samples were summed to calculate species relative frequencies (total seedlings per species/total emerged seedlings) for each wetland.

Vegetation of all wetlands was sampled in the prerestoration year (2000) and annually for 3 years postrestoration (2001-2003). Species cover classes were estimated visually with the Daubenmire cover scale and converted to percent covers using the midpoints of the scale ranges (Peet et al. 1998). In 2000, all forest layers were sampled. For woody strata greater than $1 \mathrm{~m}$ tall, total percent cover of each woody species (tree, sapling, and shrub strata inclusive) was estimated in each of three to five 0.10 -ha plots spaced systematically across the wetland interior; woody stems were also tallied by stratum (tree, sapling, shrub). In the ground layer (woody plants $<1 \mathrm{~m}$ and all herbs), covers of each species were estimated in 12 4- $\mathrm{m}^{2}$ quadrats, each located at a seed bank sample point. After the experimental wetlands were harvested in early 2001, eight $4-\mathrm{m}^{2}$ permanent ground layer quadrats were established, with two quadrats stratified by deeper and shallower elevations along each of the four original seed bank transects. Eight permanent ground layer quadrats were similarly established in the three unrestored wetlands. Species covers in all quadrats were estimated annually each August. In the experimental wetlands in late summer 2003, a redeveloping woody shrub layer (height $>1 \mathrm{~m}$ ) was sampled with eight $25-\mathrm{m}^{2}$ plots co-located with the permanent quadrats.

\section{Analyses}

The unit of replication for analysis was the individual wetland; therefore, data were averaged across quadrats to estimate percent cover of each species per year. In the prerestoration year, mean species covers were estimated both for all forest strata and for the ground layer. All identified plant species were grouped into three classes according to their wetland indicator category, an acronym system that ranks the degree of affinity for wetland habitats (Reed 1988). For analysis, we grouped OBL and FACW categories (species with $67-100 \%$ probability of 
occurring in wetlands) as true "wetland" species, FAC + and FAC categories (equally likely to occur in wetland or upland habitats) as "facultative" species, and FAC-, FACU, and UPL categories (species not considered to be wetland indicators) as "upland" species. For each wetland, we calculated the number of species and percent cover of each wetland indicator group, as well as total species richness (all species) and total vegetative cover (sum of all species covers).

We excluded one experimental wetland from analysis because it differed noticeably in having more wetland-like initial vegetation and in being harvested a year later than the other sites. For the remaining 15 experimental wetlands, we used repeated-measures analysis of variance (ANOVA) to test the difference across the four study years in the variables of total species richness, total vegetative cover, and the distributions of species number and cover among the three indicator groups. With repeated measures, replicate subjects (wetlands) essentially act as their own controls (Zar 1999), and the year effect (withinwetland factor) implicitly tests how the variables responded to the restoration manipulations after year 0 . Data generally conformed to model assumptions, but percent covers were log-transformed to improve normality. Preliminary analyses including the upland buffer management treatment (see Project Design) as a betweenwetland (split-plot) factor showed no significant buffer treatment effect or treatment-by-year interaction for any variable; therefore, we present the pooled ANOVA models testing only the year effect ( $d f=3,42$ for all tests). For significant models, statements regarding sequential between-year differences are based on post hoc tests with an adjusted significance level of $p=0.017$ (0.05/3 tests). The three unrestored wetlands changed little over time and were not needed to test restoration responses in the experimental wetlands, but summary data are noted in the Results.

Percent similarity in species composition between the seed bank and the initial vegetation was calculated for each wetland using the Sorenson index, and paired-sample tests (Wilcoxon signed ranks) were used to compare average similarity pre- and postrestoration. Densities of common woody species in the shrub layers of the experimental wetlands were also compared between year 0 and year 3 using Wilcoxon tests. All data were analyzed using SYSTAT (SPSS Inc. 1999). Note that for data reporting, 2000 is year 0 (prerestoration), 2001 is postrestoration year 1 , and so on.

\section{Results}

\section{Wetland Hydrologic Response}

Hydrologic recovery was slowed because the experiment was inadvertently started during a progressive regional drought (Fig. 1). In the prerestoration year (2000, year 0), the second year of below-normal rainfall, the experimen-
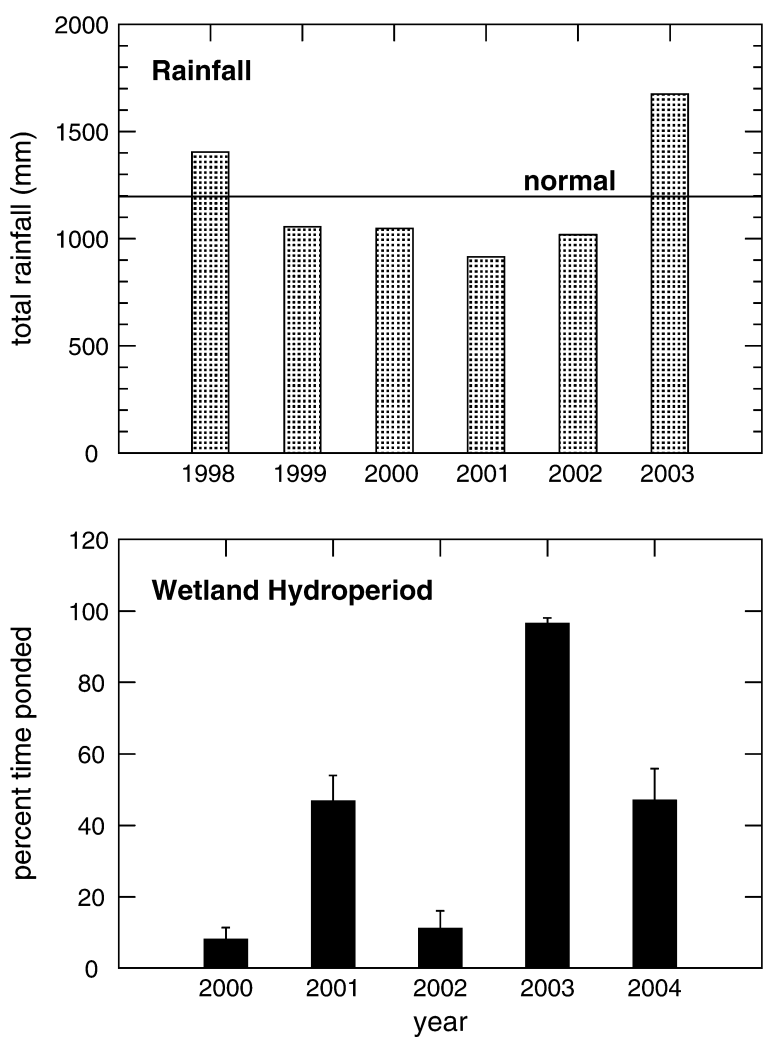

Figure 1. Annual rainfall at the SRS and annual growing-season hydroperiods (percent time ponded) in the 15 experimental wetlands, where 2000 is the prerestoration "year 0." Line for normal rainfall represents the 30-year average. Hydroperiod data are means \pm 1 SE.

tal wetlands had minimal water ponding. In year 1, after forest removal and some heavy March rains, the wetlands held water early in the growing season, with maximum water depths averaging only $0.39 \mathrm{~m}(0.06 \mathrm{SE})$. However, apart from transient shallow ponding caused by rain events in June, most sites dried down by early- to midMay as the drought advanced. The wetlands remained dry for most of the growing season in year 2, when drought conditions were severe. It was not until year 3, when rainfall was above average, that hydroperiods resembled those of natural herbaceous depressions (ponding for 70-90\% of the growing season; Mulhouse et al. 2005b). The wetlands also ponded more deeply in year 3 , with maximum water depths averaging $0.84 \mathrm{~m}(0.05 \mathrm{SE})$. Other analyses confirmed that restoration significantly lengthened wetland hydroperiods overall, when compared to prerestoration levels and to unrestored sites (Taylor \& DeBiase 2005).

\section{Vegetation Response and Seed Bank Contributions}

Before restoration, vegetation in the experimental wetlands averaged 22 species, of which fewer than $20 \%$ were herbaceous (Table 1). Facultative species comprised more than $50 \%$ of all species, and of these, most $(94 \% \pm 2 \mathrm{SE})$ 
Table 1. Species richness, percent cover, herbaceous species contributions, and distributions of species and cover among wetland indicator groups for prerestoration seed banks and for the vegetation of the experimental wetlands each year, where year 0 is prerestoration.



Data are means ( $1 \mathrm{SE}$ ) for $n=15$ wetlands (14 for seed banks). Repeated-measures $F$ statistic tests the difference among years for each vegetation variable; all $d f=3$, 42 .

${ }^{a}$ Two year 0 means and two $F$ tests are shown: one using all forest strata, the other (in brackets) using the ground layer only.

$* p<0.01 ; * * p<0.001$.

were woody. Wetland species typically comprised about one-fourth of all species in year 0 . Prerestoration vegetative cover showed similar patterns (Table 1). Of an average $143 \%$ total cover, most (108\%) was represented by facultative and woody species. Average ground layer cover was sparse $(26 \%)$, with only about one-fourth of that $(6 \%)$ contributed by herbaceous species and by wetland species. Common species in the prerestoration vegetation (Table 2) included Loblolly pine (Pinus taeda), Sweetgum (Liquidambar styraciflua), Red maple (Acer rubrum), and oaks (Quercus spp.). Woody vines (e.g., Campsis, Smilax, Trachelospermum, Vitis) were frequent. Cover of individual herbaceous species was minimal.

In years 1 and 2, following forest harvest and summer drydowns, mean species richness increased to approximately 40, with herbaceous species dominating (Table 1 ). The number of wetland species increased 4-fold in year 1 and declined somewhat in year 2, comprising 50 and $40 \%$, respectively, of all species (difference between years 1 and 2 significant at $p<0.01$ ). Upland species richness also increased, and by year 2 represented $29 \%$ of all species. The number of facultative species changed little as most $(>70 \%)$ were woody species that had been present before restoration. Vegetative cover responded similarly (Table 1 ). Total cover declined when considering the change after forest harvest, but ground-layer cover increased substantially in the first 2 years, as did cover of wetland species and upland species. Common wetland species observed in the first 2 years (Table 2 ) included sedges and rushes in species-rich genera (Cyperus, Eleocharis, Juncus, Rhynchospora), annual panic-grass (Panicum verrucosum Muhl.), and typical forbs such as seedboxes (Ludwigia spp.) and meadow-beauties (Rhexia spp.). Common facultative herb species were witchgrasses (Dichanthelium spp.) and the sedge Carex albolutescens Schw. Upland species included weedy ruderals such as Fireweed (Erechtites hieracifolia (L.) Raf.), dog- fennels (Eupatorium capillifolium (Lam.), E. compositifolium Walter), and Broomsedge (Andropogon virginicus $\mathrm{L}$.).

Vegetation composition in years 1 and 2 resembled pre-restoration seed bank composition. The seed bank samples averaged 20 species per wetland (Table 1 ), with a collective total of 68 species. The majority $(69 \%)$ were wetland species, but $17 \%$ were upland species. Within wetlands, seed banks averaged only 7\% (2 SE) similarity to prerestoration vegetation, but similarity increased to $37 \%$ ( $3 \mathrm{SE}$ ) and $34 \%$ (2 SE) in years 1 and 2, respectively (signed-ranks tests, $p=0.001$ ). Nearly all seed bank species were herbaceous (65 of 68 ), with $77 \%$ appearing in the initial postrestoration vegetation. Conversely, of 78 herbaceous species seen in more than one wetland in the first year, $53 \%$ were detected in the seed banks. Common wetland taxa shared between seed banks and postrestoration vegetation (Table 2 ) included the various sedges and rushes (Cyperus, Eleocharis, Juncus, Rhynchospora) and annual panic-grass. Shared facultative and upland species included witch-grasses and weedy forbs such as Fireweed, dogfennels, and Juniper-leaf (Polypremum procumbens L.). The same facultative and upland witch-grasses and weedy forbs were among the $13 \%$ of seed bank species that occurred in the adjacent upland vegetation, as were an upland sedge (Cyperus retrorsus Chapman), and a few woody shrubs and vines (Rhus copallina L., Toxicodendron radicans (L.) Kuntze, Vitis rotundifolia L.).

In year 3, heavy rains and prolonged water ponding altered vegetation composition and reduced vegetative cover (Table 1). Species richness and percent herbaceous species declined to averages of 17 and $40 \%$, respectively. Numbers of wetland and facultative species also decreased, but upland species were virtually eliminated (Table 1). Similarly, total cover decreased to an average of $23 \%$, and cover of upland species was reduced to less than $1 \%$ (Table 1 ). Woody species maintained their presence, but few herbaceous species had any substantial cover 
Table 2. Mean yearly abundances of common species in the seed banks and vegetation of the 15 experimental wetlands.

\begin{tabular}{|c|c|c|c|c|c|c|c|}
\hline Species & $\begin{array}{c}\text { Species Indicator } \\
\text { Group }\end{array}$ & Life Form & Seed Banks & Year 0 & Year 1 & Year 2 & Year 3 \\
\hline Acer rubrum & facultative ${ }^{*}$ & $\mathrm{~T}$ & - & 23 & + & + & 4 \\
\hline Ampelopsis arborea & facultative & WV & - & + & - & + & - \\
\hline Campsis radicans & facultative & WV & - & 12 & 9 & 8 & 1 \\
\hline Lonicera japonica & upland & WV & - & 1 & - & - & - \\
\hline Pinus spp. (taeda, elliottii) & facultative & $\mathrm{T}$ & - & 25 & + & 2 & 4 \\
\hline Quercus laurifolia & wetland & $\mathrm{T}$ & - & 12 & - & - & - \\
\hline Quercus nigra & facultative & $\mathrm{T}$ & - & 15 & + & + & 3 \\
\hline Quercus phellos & wetland & $\mathrm{T}$ & - & 10 & - & - & 2 \\
\hline Rhus copallina & upland & $\mathrm{S}$ & + & - & + & + & - \\
\hline \multicolumn{8}{|l|}{ Herbaceous species } \\
\hline Andropogon virginicus & upland & PG & - & - & + & 2 & - \\
\hline Carex albolutescens & facultative & PS & 7 & - & 15 & 2 & + \\
\hline Cyperus (9 spp.) & wetland & A/PS & 36 & - & 12 & + & - \\
\hline Dichanthelium (12 spp.) & facultative & PG & 4 & - & 6 & 3 & - \\
\hline Eleocharis (6 spp.) & wetland & A/PS & 4 & - & 5 & - & - \\
\hline Erechtites hieracifolia & upland & $\mathrm{AF}$ & + & - & + & 5 & - \\
\hline Eupatorium capillifolium, compositifolium & upland & $\mathrm{A} / \mathrm{PF}$ & 5 & - & + & 6 & - \\
\hline Fimbristylis autumnalis & wetland & AS & 5 & - & + & - & - \\
\hline Juncus (12 spp.) & wetland & A/PS & 8 & - & + & + & - \\
\hline Lemna spp. & wetland & FL & - & - & - & - & 6 \\
\hline Ludwigia (11 spp.) & wetland & $\mathrm{PF}$ & + & - & 2 & + & + \\
\hline
\end{tabular}

Abundance is relative frequency (seed bank) or percent cover (vegetation). For each sample, values are given only for species found in greater than or equal to $50 \%$ of wetlands and at greater than or equal to $10 \%$ abundance in at least one wetland ( $\geq 5 \%$ in year 3 ). + indicates species found in greater than or equal to $50 \%$ of wetlands but at lower abundance.

$\mathrm{AF}=$ annual forb, $\mathrm{AG}=$ annual grass, $\mathrm{AS}=$ annual sedge, $\mathrm{FL}=$ floating aquatic, $\mathrm{PF}=$ perennial forb, $\mathrm{PG}=$ perennial grass, $\mathrm{PS}=$ perennial sedge, $\mathrm{S}=$ shrub, $\mathrm{T}=$ tree, $\mathrm{WV}=$ woody vine.

*Sometimes considered a wetland species in the Coastal Plain region (Godfrey \& Wooten 1981).

(Table 2). Floating and submersed aquatics such as duckweeds (Lemna, Spirodela) and bladderworts (Utricularia spp.), and the emergent rush Scirpus cyperinus (L.) Kunthe, were among the more common species observed in year 3. These aquatic species were not detected in the seed bank samples.

Though forest harvest removed most woody cover, some woody species persisted at low abundances in the ground layer. Many resprouted after harvest, particularly as the foliar herbicide application in year 1 was ineffective in preventing stump sprouting thereafter. By year 3, a taller shrub/sapling layer had redeveloped, bringing mean total cover to $36 \%$ (6 SE) and mean facultative species cover to $20 \%$ (4 SE) as compared to $23 \%$ total and $9 \%$ facultative cover in the ground layer (cf. Table 1). Sapling density of three taxa (pine, Sweetgum, and oaks) increased significantly from prerestoration levels (Table 3). The pines were mainly new seedlings, but most Sweetgum and oaks were resprouts from stumps left after harvest.

In the three unrestored wetlands, forest composition resembled that of the experimental wetlands in year 0 (see Project Design) and changed little over the study period (average similarity between years of $84-87 \%$ ). Species richness averaged 18-27 species per year, and woody species remained dominant at averages of $70-90 \%$ of all species and $>95 \%$ of total cover. Ground layer vegetation cover averaged $26 \%$ or less per year and changed little in 
Table 3. Stem density and percent cover of common woody species appearing in the shrub layer of experimental wetlands by year 3, as compared to their shrub-layer density in year 0 .

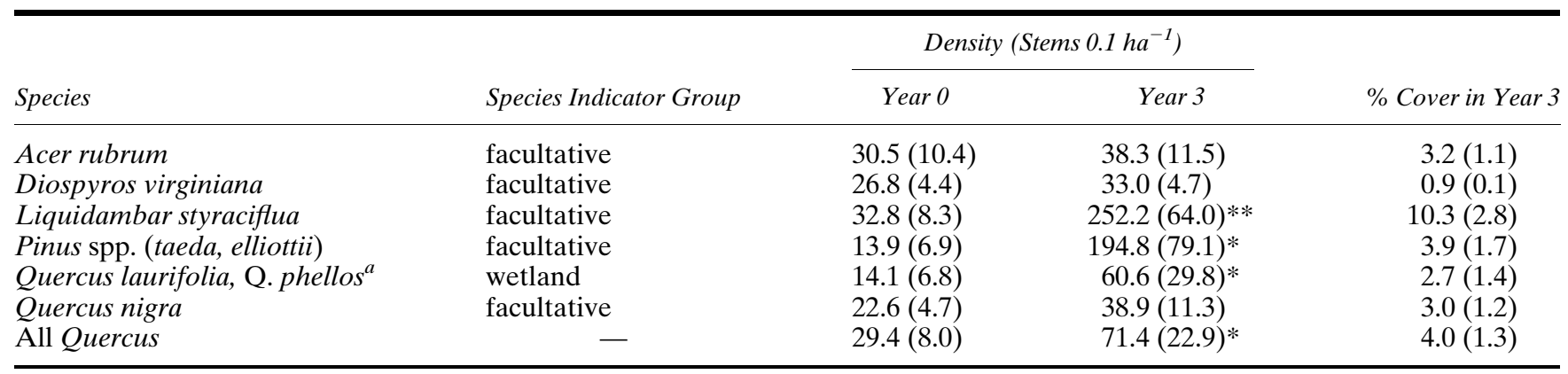

Data are means (1 SE) for $n=15$ wetlands. Significant increases in stem density are indicated by $* p<0.05 ; * * p<0.01$.

${ }^{a}$ Species difficult to distinguish as saplings.

plant composition over time (repeated-measures ANOVA tests for year effects: all $d f=3,6$; all $p>0.10)$.

\section{Discussion}

In the absence of deliberate planting, it is unlikely that these restored coastal plain depressions would fully resemble natural reference wetlands within a 3-year time period. The short-term restoration goal is emergent (herbaceous) vegetation dominated $(\geq 50 \%$ cover $)$ by true wetland species. During the first few years, any potential for seed banks and rapidly colonizing species to establish a trajectory toward the desired goals should be evident. Our results provided some evidence that passive revegetation can be a successful strategy. First, after removal of forest dominated by facultative woody species, the restored wetlands quickly developed a dense cover of herbaceous species, roughly half of which were wetland species in the first year. Second, seed banks contributed many wetland species to the restored vegetation; the number of shared species was likely underestimated because seed bank sampling was limited spatially and uncommon species are less likely to be detected (Leck 1989; van der Valk \& Pederson 1989). However, other results indicated some limitations to a passive approach. Hydrologic recovery was slowed by unpredictable drought conditions, which allowed "nonwetland" (i.e., facultative and upland) species to establish from seed banks and dispersal or to persist after site preparations. Preliminary assessments also suggest that species composition of the restored sites differs in several respects from that of natural herbaceous depression wetlands.

Despite their past disturbance history, the experimental wetlands had seed banks with diverse species that quickly emerged within the first year after forest harvest. Common wetland species contributed to the initial vegetation by the seed bank were emergent sedges and forbs (e.g., Cyperus, Eleocharis, Juncus, Ludwigia, Rhynchospora, Rhexia) whose establishment is favored by shallow water or water drawdown. These species are not wind-dispersed and thus were unlikely to have colonized immediately by dispersal from distant source wetlands. In addition to any relict wetland species from the historical predisturbance vegetation, the seed banks likely also contained seed inputs accumulated during several decades of forest succession within the wetlands. Nonwetland seed bank species included early successional ruderals (e.g., Fireweed, dogfennels, Broomsedge) typically found in regenerating upland forest clearcuts; these weedy species disperse readily by wind but are not flooding-tolerant. Even in undisturbed depression wetlands, seed banks contain species that may colonize from the surrounding upland landscape of managed forests and riparian wetlands (Poiani \& Dixon 1995; Mulhouse et al. 2005a).

Depressional wetlands lack natural inlets or outlets; thus, hydrologic regimes are strongly controlled by fluctuations in annual rainfall. Because periodic drought cycles are a natural but unpredictable occurrence in the southeastern United States, they present an inherent restoration challenge. In this study, drought conditions influenced the interaction between seed banks and initial revegetation, which was similar across all wetlands. Wetland drying during the first year favored establishment of both wetland and nonwetland species, and the nonwetland species increased in cover as the drought progressed through the second year. However, deep and long ponding in the third year reduced vegetative cover but particularly suppressed upland herbaceous species. Thus, the potential exists for a self-designed vegetative cover dominated by wetland plants, depending upon the final hydrologic regimes that become established in individual wetlands. Increased permanence of ponding would strongly select for wetland species, whereas more seasonal ponding could allow facultative and upland species to persist in the drier wetland margins and to expand centrally during droughts. This dynamic pattern is seen in undisturbed seasonally ponded depressions (Kirkman 1995; Stroh 2004; Mulhouse et al. 2005a).

The early drought also promoted an undesired founder effect in the form of woody regeneration and resprouting of facultative tree species. Based on a preliminary study (Singer 2001), it was expected that early ponded conditions could suppress stump sprouting of harvested trees. 
Instead, the drought precluded any prolonged early flooding to drown the cut stumps. In addition, other planned control measures could not be fully implemented: drought restrictions prevented using slash reduction fires to kill woody stems immediately after harvest, and the single application of foliar herbicide did not prevent further resprouting. If the restored wetlands continue to pond substantial water as in year 3, the less flood-tolerant pines and oaks may become stressed and die-back (e.g., Kirkman 1995; Stroh 2004). However, Sweetgum and Red maple tolerate shallow seasonal flooding and sprout vigorously; such woody sprouts, where dense, could eventually shade out the herbaceous cover. Thus, the timing of ponding in relation to site preparations may be a critical influence on the future trajectory of revegetation.

Passive methods can successfully establish wetland plant species, but they may not fully replicate the vegetation composition of natural reference systems. For example, in restorations of formerly drained prairie potholes, some wetland species groups appeared readily but others failed to recolonize (Galatowitsch \& van der Valk 1996; Seabloom \& van der Valk 2003). The absent species were poorly represented in the seed banks and could not easily disperse to isolated wetlands surrounded by farmlands; many restored potholes also became dominated by invasive perennial species such as Reed canary grass (Phalaris arundinacea L.) (Mulhouse \& Galatowitsch 2003). Similarly, in our study, the initial restored vegetation had many species commonly found in natural herbaceous depression wetlands (De Steven \& Toner 2004) but lacked two characteristic plant groups. First, aquatic species were not detected in the seed banks, and few colonized the ponded wetlands in year 3. Second, typical dominant perennial grasses and sedges, such as maidencane (Panicum hemitomon Schult.), Southern cutgrass (Leersia hexandra Sw.), and Peatland sedge (Carex striata Michx.), were largely absent in the seed bank samples and did not appear in the vegetation, except in a few sites where they had been present before restoration. Aquatic plants, often dispersed by waterfowl, successfully colonized restored prairie pothole wetlands (Galatowitsch \& van der Valk 1996). This suggests that aquatic species could colonize our experimental wetlands with time, if favorable ponding conditions persist and attract wetland birds. In contrast, the three dominant grass/sedge species reproduce by vegetative propagation but have limited means of seed dispersal; thus, active planting of these species may be needed to restore them to the vegetation (see Barton et al. 2004). Unlike the case in prairie pothole restorations, we have observed little or no colonization by invasive exotic plants to date.

Our study demonstrated partial support for a passive restoration approach for coastal plain depression wetlands, but the results may not apply generally in all situations. Our experimental wetlands occurred within a forested landscape and had been successional for at least several decades. They also ponded some water for brief periods despite the presence of functioning drainage ditches (Dietz-Brantley et al. 2002). Thus, the wetland species in the seed banks could have colonized the sites over some time. By contrast, disturbed depressions in agricultural landscapes could be more difficult to restore passively because their seed banks may lack wetland species and the surrounding farmlands would have few nearby wetland sources for seed dispersal. This possibility is suggested by the studies of prairie potholes, where it appeared that viability of wetland species in the seed banks declined after a few decades of agricultural drainage (van der Valk \& Pederson 1989; Wienhold \& van der Valk 1989). Our findings indicate that seed bank analysis could be used to assess the potential for successful passive revegetation of coastal plain depressions in such agricultural settings. Where seed banks are depauperate of wetland species, planting of selected wetland species may be desirable. We expect the longer-term results of our project to provide additional guidelines in designing future restoration efforts for these important and unique Coastal Plain wetlands, as well as for depressional wetlands elsewhere.

\section{Acknowledgments}

We gratefully acknowledge funding provided by the U.S. DOE-Savannah River Operations Office under Interagency Agreements DE-IA09-76SR00056 and DE-IA0900SR22188 with the USDA Forest Service-Savannah River, by the Environmental Remediation Sciences Division of the U.S. DOE Office of Biological and Environmental Research (Award DE-FC09-96SR18546 to The University of Georgia Research Foundation), by Cooperative Agreement 01-CA-11330135-457 with the USDA Forest Service Southern Research Station, and by the Southern Research Station's Center for Forested Wetlands Research. For field assistance, we especially thank J. Mulhouse, A. Lowrance, P. Stankus, A. Brinton, A. Prescott, M. Smith, J. Mason, B. Allen, L. Zorn, and M. Opdyke, as well as other SREL and USFS staff. Statistical review and helpful comments on the manuscript were provided by S. Zarnoch, B. Collins, D. Imm, and D. Ryder. We also thank R. LeBlond, North Carolina Natural Heritage Program, for assistance with Dichanthelia identification.

\section{LITERATURE CITED}

Barton, C. D., D. De Steven, and J. C. Kilgo. 2004. Mitigation bank promotes research on restoring coastal plain depression wetlands. Ecological Restoration 22:291-292. URL http://www.srs.fs.usda. gov/pubs/9713.

Bennett, S. H., and J. B. Nelson. 1991. Distribution and status of Carolina bays in South Carolina. Nongame and Heritage Trust Publication No. 1. South Carolina Wildlife and Marine Resources Department, Columbia.

Collins, B. S., and L. L. Battaglia. 2001. Hydrology effects on propagule bank expression and vegetation in six Carolina bays. Community Ecology 2:21-33. 
De Steven, D., and M. M. Toner. 2004. Vegetation of upper coastal plain depression wetlands: environmental templates and wetland dynamics within a landscape framework. Wetlands 24:23-42.

Dietz-Brantley, S. E., B. E. Taylor, D. P. Batzer, and A. E. DeBiase. 2002. Invertebrates that aestivate in dry basins of Carolina bay wetlands. Wetlands 22:767-775.

Edwards, A. L., and A. S. Weakley. 2001. Population biology and management of rare plants in depression wetlands of the southeastern coastal plain, USA. Natural Areas Journal 21:12-35.

Environmental Laboratory. 1987. Corps of engineers wetland delineation manual. Technical Report Y-87-1. U.S. Army Engineer Waterways Experiment Station, Vicksburg, Mississippi.

Galatowitsch, S. M., and A. G. van der Valk. 1996. The vegetation of restored and natural prairie wetlands. Ecological Applications 6:102-112.

Godfrey, R. K., and J. W. Wooten. 1981. Aquatic and wetland plants of the southeastern United States. University of Georgia Press, Athens.

Kirkman, L. K. 1995. Impacts of fire and hydrological regimes on vegetation in depression wetlands of southeastern USA. Pages 10-20 in S. I. Cerulean, and R. T. Engstrom, editors. Fire in wetlands: a management perspective. 19th Tall Timbers Fire Ecology Conference Proceedings. Tall Timbers, Inc., Tallahassee, Florida.

Kirkman, L. K., R. F. Lide, G. Wein, and R. R. Sharitz. 1996. Vegetation changes and land-use legacies of depression wetlands of the western coastal plain of South Carolina: 1951-1992. Wetlands 16:564-576.

Kirkman, L. K., and R. R. Sharitz. 1994. Vegetation disturbance and maintenance of diversity in intermittently flooded Carolina bays in South Carolina. Ecological Applications 4:177-188.

Leck, M. A. 1989. Wetland seed banks. Pages 283-305 in M. A. Leck, V. T. Parker, and R. L. Simpson, editors. Ecology of soil seed banks. Academic Press, San Diego, California.

Mitsch, W. J., and R. F. Wilson. 1996. Improving the success of wetland creation and restoration with know-how, time, and self-design. Ecological Applications 6:77-83.

Mulhouse, J. M., L. E. Burbage, and R. R. Sharitz. 2005a. Seed bankvegetation relationships in herbaceous Carolina bays: responses to climatic variability. Wetlands 25:738-747.

Mulhouse, J. M., D. De Steven, R. F. Lide, and R. R. Sharitz. $2005 b$. Effects of dominant species on vegetation change in Carolina bay wetlands following a multi-year drought. Journal of the Torrey Botanical Society 132:411-420.

Mulhouse, J. M., and S. M. Galatowitsch. 2003. Revegetation of prairie pothole wetlands in the mid-continental US: twelve years postreflooding. Plant Ecology 169:143-159.

Palmer, M. A., R. F. Ambrose, and N. L. Poff. 1997. Ecological theory and community restoration ecology. Restoration Ecology 5:291-300.

Pechmann, J. H. K., D. E. Scott, J. W. Gibbons, and R. D. Semlitsch. 1989. Influence of wetland hydroperiod on diversity and abundance of metamorphosing juvenile amphibians. Wetlands Ecology and Management 1:3-11.

Peet, R. K., T. R. Wentworth, and P. S. White. 1998. A flexible, multipurpose method for recording vegetation composition and structure. Castanea 63:262-274.
Poiani, K. A., and P. M. Dixon. 1995. Seed banks of Carolina bays: potential contributions from surrounding landscape vegetation. American Midland Naturalist 134:140-154.

Reed, P. B. Jr. 1988. National list of plant species that occur in wetlands: national summary. US Fish and Wildlife Service, Washington, D.C. Biological Report 88(24).

Seabloom, E. W., and A. G. van der Valk. 2003. Plant diversity, composition, and invasion of restored and natural prairie pothole wetlands: implications for restoration. Wetlands 23:1-12.

Sharitz, R. R. 2003. Carolina bay wetlands: unique habitats of the southeastern United States. Wetlands 23:550-562.

Sharitz, R. R., and C. A. Gresham. 1998. Pocosins and Carolina bays. Pages 343-377 in M. G. Messina, and W. H. Conner, editors. Southern forested wetlands: ecology and management. CRC Press/Lewis Publishers, Boca Raton, Florida.

Singer, J. H. 2001. Effect of overstory removal and fire on wetland vegetation and recruitment from the seed bank in a hydrologically restored Carolina bay wetland. M.S. thesis. University of Georgia, Athens.

Snodgrass, J. W., A. L. Bryan Jr, R. F. Lide, and G. M. Smith. 1996. Factors affecting the occurrence and structure of fish assemblages in isolated wetlands of the upper coastal plain, U.S.A. Canadian Journal of Fisheries and Aquatic Science 53:443-454.

South Carolina State Climatology Office. 2004. General description of South Carolina's climate, and severe weather extremes. South Carolina Department of Natural Resources, Columbia. URL http:// www.dnr.state.sc.us/climate/sco/ [accessed April 2004].

Southern Environmental Law Center. 2004. At risk: South Carolina's "isolated" wetlands. SELC, Chapel Hill, North Carolina.

SPSS, Inc. 1999. SYSTAT version 9. SPSS, Inc., Chicago, Illinois.

Stroh, C. L. 2004. Vegetation dynamics in Carolina bays: response to drought cycles over a 15-year period. M.S. thesis. The College of Charleston, Charleston, South Carolina.

Taylor, B. E., and A. E. DeBiase. 2005. Are microcrustaceans useful for assessing success of wetland pond restoration? Ecological Restoration 23:56-57.

Taylor, B. E., D. A. Leeper, M. A. McClure, and A. E. DeBiase. 1999. Carolina bays: ecology of aquatic invertebrates and perspectives on conservation. Pages $167-195$ in D. P. Batzer, R. B. Rader, and S. A. Wissinger, editors. Invertebrates in freshwater wetlands of North America: ecology and management. John Wiley \& Sons, Inc., New York

Tiner, R. W. 2003. Geographically isolated wetlands of the United States. Wetlands 23:494-516.

van der Valk, A. G., and R. L. Pederson. 1989. Seed banks and the management and restoration of natural vegetation. Pages 329-346 in M. A. Leck, V. T. Parker, and R. L. Simpson, editors. Ecology of soil seed banks. Academic Press, San Diego, California.

Wienhold, C. E., and A. G. van der Valk. 1989. The impact of duration of drainage on the seed banks of northern prairie wetlands. Canadian Journal of Botany 67:1878-1884.

Zar, J. H. 1999. Biostatistical analysis. 4th edition. Prentice-Hall, Inc., Upper Saddle River, New Jersey. 